\title{
Estética e poética da modernidade em Charles Baudelaire
}

Dilmar Miranda

Prof. Associado do curso de Filosofia da UFC

\begin{abstract}
Resumo - O presente texto visa contextualizar uma importante fração do tempo do artista/pensador francês Charles Baudelaire, a Paris, capital do século XIX, que exerceu um incomensurável fascínio ao filósofo alemão Walter Benjamin, cujo pensamento em parte significativa de sua obra lhe foi dedicada, denominando-o um lírico no auge do capitallismo. O flâneur, as multidões, as passagens cobertas são alguns dos temas favoritos dos dois pensadores. Baudelaire, poeta atento aos rumores dos novos tempos, cunha o termo modernidade, conceito fundamental para entendermos o anúncio das rupturas com a poética e a estética da tradição e que apontam para os novos cânones que estão por vir.
\end{abstract}

Palavras-chave: Baudelaire, passagens, modernidade, multidão, flâneur.

Abstract - This paper aims to contextualize an important fraction of the time of the French artist/thinker Charles Baudelaire, the Paris, capital of the nineteenth century, which exerted an immense fascination to the German philosopher Walter Benjamin, whose a significant part of his thought was dedicated to Baudelaire, calling him A lyric poet in the Era of High Capitalism. The flâneur, the crowds, the covered passages, are some of the favorite subjects to the two thinkers. Baudelaire, poet aware of the rumors of the new times, coins the term modernity, essential concept to understanding the announce of the ruptures with the aesthetic and poetic of the tradition, and pointing to the new canons to come.

Keywords: Baudelaire, covered passages, modernity, crowd, flâneur.

\section{O tempo de Charles Baudelaire}

... e escutar os rumores do dia como se fossem os acordes da eternidade (Karl Kraus).

\author{
Allez, amoureux de Paris, \\ ...... \\ Allez, et sous ces claires verrières, \\ loin des vacarmes de dehors, \\ écoutez dans la fuite des temps, \\ battre le coeur \\ de la ville que vouz aimez. \\ (Les passages parisiens, Maurice Bedel, ${ }^{1}$
}

\footnotetext{
1 “Vós, amantes de Paris,... Vós, sob essa translucidez vítrea, Afastados do burburinho das ruas, Escutai, no fluxo de tempos atrás, Bater o coração Da cidade que tanto amais".
} 
Une façon de percevoir l'ambiguité, la double signification des passages: les richesses en miroirs, qui donne aux espaces une ampleur fabuleuse et rend plus difficile l'orientation.

Car ce monde de miroirs peut bien avoir plusieurs significations et même une infinité de significations, [...]. (Paris, capitale du XIXe siècle, le livre des passages, Walter Benjamin) ${ }^{2}$

Existem pessoas singularmente sensíveis aos sentidos de mudança submersos no curso da história, ao perceber a importância de sua época, quando frações do tempo parecem condensar anos, ao provocar profundas rupturas, liberando um magma desconstrutor/reconstrutor, para abrir novas perspectivas e inúmeras possibilidades de criação nos mais diferentes domínios da ação humana. Charles Baudelaire (1821-1867) foi certamente, com relação ao seu tempo, uma dessas pessoas.

O poeta compõe a galeria de artistas/pensadores ${ }^{3}$ que surgem em determinado momento da vida cultural europeia. Ele pode ser considerado como o primeiro grande artista/pensador a sinalizar rupturas com os principais cânones da estética da tradição que vigeram durante séculos, como a questão do belo ideal, da arte mimética, da aura e perdurabilidade da obra de arte, dentre outros, contrapondo ao status quo estético da sua época. A sua ênfase dada à inventiva da subjetividade criadora do artista abriu caminhos para o que passou a ser conhecido como arte moderna.

Eis como Baudelaire enxerga a estética de seu tempo:

"Esta é uma bela ocasião para estabelecer uma teoria racional e histórica do belo, em oposição à teoria do belo único e absoluto; para mostrar que o belo inevitavelmente sempre tem uma dupla dimensão, embora a impressão que produza seja una [...]. O belo é constituído por um elemento eterno, invariável, [...] e por um elemento relativo, circunstancial, que será, se quisermos, [...] a época, a moda, a moral, a paixão" (1995, p. 852).

Mas qual foi o tempo do poeta? A Paris, capital do século XIX - conforme a designava Benjamin - além das rápidas transformações provocadas pela Revolução Industrial,

(Todos os textos originais em francês foram traduzidos, de forma livre, pelo autor, exceto o soneto $A$ une passante e os versos alexandrinos extraídos do poema Le soleil, das Fleurs du mal, traduzidos por Ivan Junqueira).

2 "Um modo de perceber a ambiguidade, a dupla significação das passagens: sua riqueza em espelhos, que empresta aos espaços uma amplitude fabulosa e torna mais difícil a orientação. Pois esse mundo de espelhos pode possuir certamente múltiplos sentidos, e mesmo, uma infinidade de sentidos, [...]".

${ }^{3}$ Artista/pensador: determinada personalidade do mundo das artes que surge, a partir do período préromântico europeu, e que aliava o fazer artístico com a reflexão crítico-filosófica, provocando fortes ressonâncias nos rumos da vida cultural subsequente. Além de Baudelaire ( $O$ pintor da vida moderna e outros ensaios), fazem parte dessa galeria Goethe (Escritos sobre arte), Schiller (A educação estética do homem), Richard Wagner (Obra de arte do futuro e Ópera e drama). Com incidência menor, encontramos em outras épocas artistas/pensadores, a exemplo do polímata humanista do Renascimento Leonardo Da Vinci. 
sofria igualmente, desde a Revolução de 1789, uma febre especulativa do solo urbano, a partir das expropriações das propriedades da nobreza destronada e dos prédios da igreja comprometida com o Ancien Régime. Muitos edifícios religiosos foram destruídos, liberando seus terrenos que passaram a ser colocados a serviço da especulação privada.

Segundo a historiadora Adeline Daumard, "a Revolução acelerou o processo de enriquecimento rápido ao injetar no mercado um inestimável número de imóveis onde o capital acumulado podia investir celeremente e com excelente resultado". 4

Por outro lado, o fim das guerras napoleônicas, a partir do segundo decênio do século XIX, propiciara uma paz relativa, ao fazer cessar a drenagem de recursos públicos para o esforço de guerra, criando assim uma atmosfera favorável à prosperidade econômica e à transformação física e social de Paris.

Entre 1820 e as vésperas da revolução de 1848, a riqueza de setores do comércio e do capital financeiro mais do que dobra. A febre imobiliária faz multiplicar prédios e fortunas. Esses grandes especuladores se compraziam em erguer quarteirões inteiros, interligados pelas famosas passagens cobertas, para ostentar sua própria glória. "Índices da afirmação grandiloquente da burguesia comercial parisiense, as aberturas das passagens significaram uma ruptura urbanística radical, ofertando novos modos de consumir e caminhar". 5

Lembremos que a Paris pré-Haussmann, ${ }^{6}$ além dos espaços mais abertos das places royales (praças da realeza), vestígios do Ancien Régime, era entretecida por um emaranhado de estreitas e tortuosas ruelas e becos de herança medieval, de ruas inseguras, sujas e escuras. Assim como outras capitais europeias, Paris carecia de planejamento no traçado de suas vias públicas, de pavimentação para os veículos de tração animal e de calçadas para o fluxo dos pedestres, bem como de serviço de esgoto

\footnotetext{
4 “La Révolution a accéléré le processus de l'enrichessiment en jetant sur le marché une masse d'immeubles où les capitaux pouvaient s'investir rapidement et à bon compte" ("La Bourgeoisie aux XIXe Siècle", apud Delorme e Dubois, 2002, p. 14).

5 "Indices de l'affirmation grandissante de la bourgeoisie commerçante parisienne, les percements des passages signifièrent une rupture urbanistique radicale, offrant de nouveaux modes de consommation et de cheminement (Delorme e Dubois, 2002, p.9).

6 O barão George-Eugène Haussmann (1809-1891), prefeito de Paris (1853-1870) nomeado por Napoleão III, foi autor da primeira e gigantesca intervenção urbana dos tempos modernos da Europa, conhecida como "Reformas do 20 Império", pondo abaixo a Paris de herança medieval, rasgando e iluminando grandes e largas avenidas e bulevares, erigindo majestosos monumentos, enfim modernizando a capital, visando, sobretudo, evitar a ação das classes dangereuses (classes perigosas) e de revoltosos, como ocorrera na Revolução de 1848. Tal obra serviu de modelo para diversas cidades, inclusive para o engenheiro Pereira Passos, prefeito do Rio de Janeiro, autor da "operação bota-abaixo" (1904), demolindo o centro carioca de "morrinha colonial" (expressão do poeta Olavo Bilac), perseguindo o modo de vida europeu, pela modernização da recém instituída capital da República, sob a égide de uma espécie de estética tropical da belle époque (v. Needell, 1993).
} 
ou outros serviços de interesse coletivo. Benjamin chama a atenção para essa Paris préHaussmann, citando o escritor e fotógrafo amador Maxime Du Camp, que muito dissertara sobre a Paris da segunda metade do século XIX.

"Haussmann começou sua obra em 1859. Já estava esboçada por projetos de lei e pressentida na sua necessidade. Du Camp escreveu [...]: 'Paris, após 1848, estava na iminência de se tornar inabitável. A constante expansão da rede ferroviária ... acelerava o tráfego e o aumento da população da cidade. As pessoas sufocavam nas velhas ruas, estreitas, sujas, confusas, em que estavam metidas como em redil porque não havia outra solução'" (Benjamin, 2000a, p.20s).

Delphine de Girardin, outra arguta observadora dessa época, assim descreve, em 1835, os costumes da Paris que transformavam a vida dos pedestres em verdadeiro pesadelo: "Nas ruas e bulevares, a circulação atual é impossível. Nos dias de chuva, poças de lama nos mantêm imóveis de todos os lados; nos dias de sol, a multidão acha-se tão compactada que não se consegue dar um passo sequer". ${ }^{7}$

O comércio citadino, constituído pelo aflorar de novas demandas mais afeitas às sociedades urbano-industriais, provocando novos hábitos de consumo, encontra nas galerias cobertas, um via alternativa para oferecer aos seus possíveis clientes, o abrigo seguro contra as intempéries, a higiene, o conforto e o luxo necessários para exibir produtos em suas vitrines feéricas.

As passagens, espécie de pequenas ruas interiores cobertas, exibem, via de regra, uma arquitetura exuberante. Graças à combinação dos telhados formatados em verrières et fer (tetos envidraçados montados em armações de ferro), de onde pendem luxuosos lustres, com imponentes paredes espelhadas, ilusionam os passantes com relação à sua amplitude, conforme diz Benjamin, ostentando ricas decorações em madeira e mármore, esculturas e colunas neoclássicas, arabescos e pinturas em afrescos, algumas com motivos egípcios, erigidas sobre belos pisos com esplêndidos desenhos em mosaicos multicoloridos, concentrando e interligando vários tipos de negócios para diferentes funções como hotéis, museus, cafés, bistrôs, salões de chá, confeitarias, livrarias (bouquinistes), antiquários, lojas de brinquedo, butiques de moda masculina e feminina, magazines e outros empreendimentos de diversos gêneros.

\footnotetext{
7 "Dans les rues et sur les Boulevards, la circulation est maintenant impossible. Les jours de pluie, des lacs de boue vous arrêtent de tous cotés; les jours de soleil, la foule est si pressée qu'on ne peut faire un pas" (Girardin, apud Delorme e Dubois, op. cit. 12).
} 


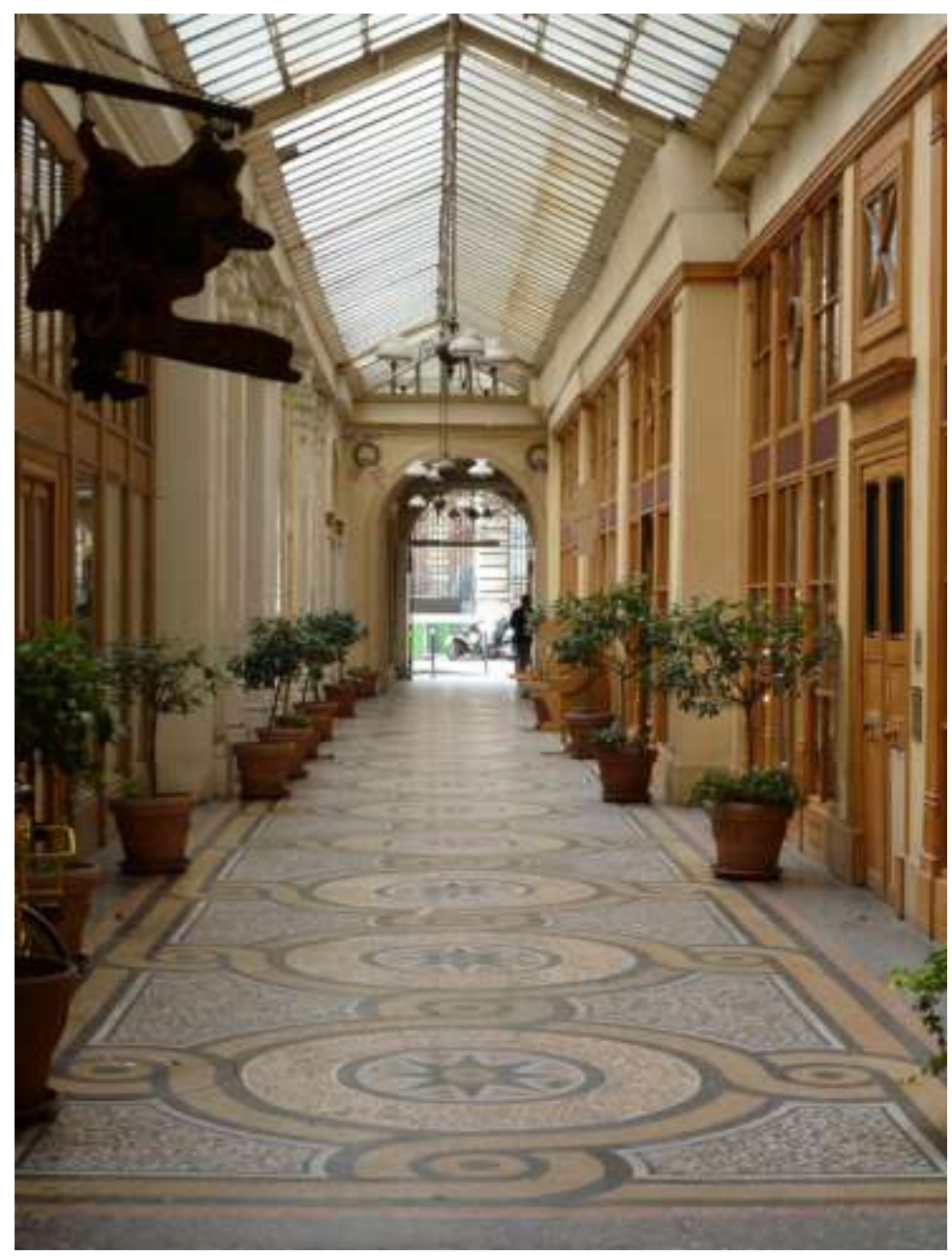

Galerie Vivienne (projeto do arquiteto François Jean Dellanoy - foto do autor

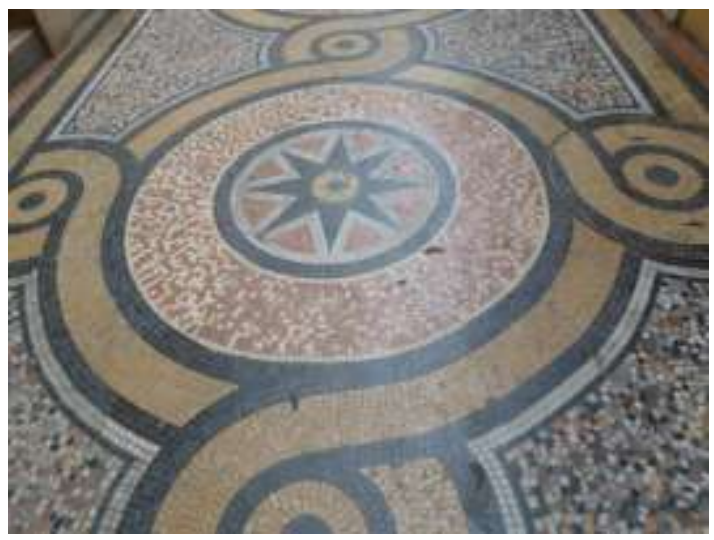

Detalhe do mosaico do chão da Galerie Vivienne (criação de Gian Domenico Fachinna) -

foto do autor

A edificação de muitas passagens cobertas na região dos Grands Boulevards, nas imediações do Palácio Brongniart, fala por si só. Esta impressionante edificação neoclássica destinada à Bolsa de Valores de Paris até 1987, templo do mundo dos negócios e importante equipamento do incipiente capitalismo industrial francês, 
iniciado no tempo de Napoleão Bonaparte, é emoldurada por um majestoso peristilo de estilo coríntio, no bairro Vivienne, nome igualmente dado a uma das mais belas passagens parisienses (fotos acima), construída em 1823, e a seu lado, a Galerie Colbert,

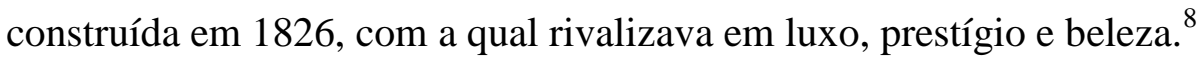

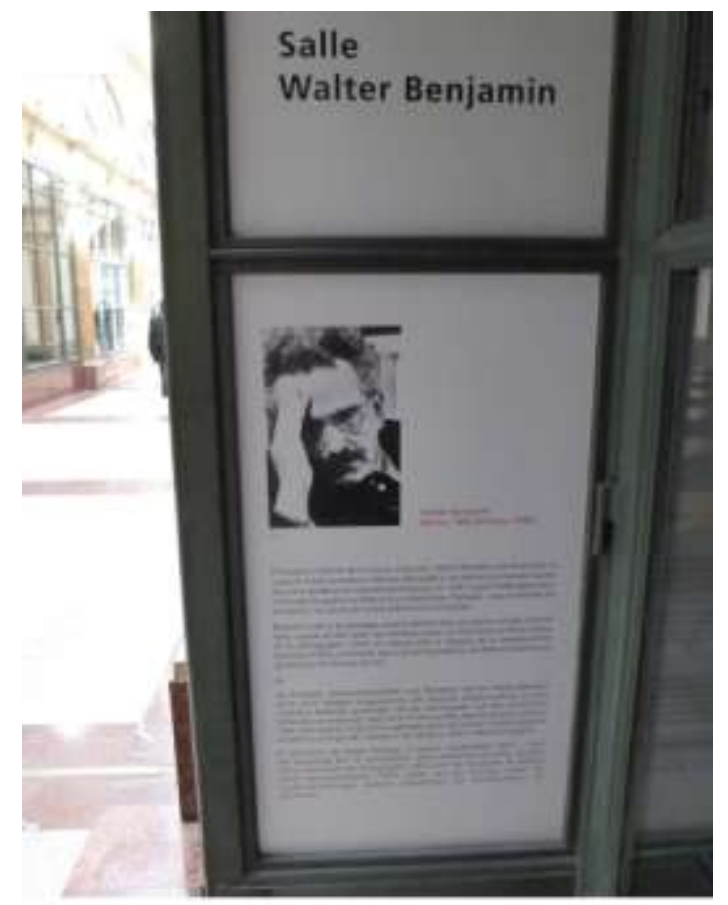

Salle Walter Benjamin na Galerie Colbert - foto do autor

Além das passagens cobertas, os paronamas e os dioramas, ${ }^{9}$ as exposições universais, o destino da arte de seu tempo, as ruas, as multidões, os novos hábitos e

\footnotetext{
${ }^{8}$ Numa das alas da Galeria Colbert encontra-se hoje a Salle Walter Benjamin (foto acima).

9 O panorama e o diorama, nomes originários do étimo orama ("ver" em grego), engenhosos inventos para o entretenimento na Paris do Século XIX, são considerados precursores do cinema (v. citação abaixo de Benjamin). O panorama, que, além do termo orama, tem o prefixo pan ("todo" em grego). foi inventado em fins do século XVIII pelo retratista inglês Robert Baker, que batiza sua criação com o título francês La Nature à coup d'oeil (a natureza num piscar de olhos), tendo como fonte de inspiração o teatro de sombras chinês. Benjamin assim o descreve: "antes do cinema começar a formar seu público, as pessoas já se reuniam em torno do Panorama imperial [Kaiserpanorama] para ver imagens [animadas]. O público se colocava diante de um biombo onde eram instalados vários estereoscópios, cada um direcionado para um dos espectadores. Diante desses aparelhos, apareciam automaticamente imagens sucessivas, que persistiam um instante antes de dar lugar à seguinte" (2008, L'oeuvre d'art à l'époque de sa reprodutctibilité technique - version de 1939, nota p. 45; tradução livre do autor).

O diorama, cujo termo foi criado por um dos inventores da fotografia, Louis Daguerre, em 1822, era um quadro iluminado na sua parte superior por uma luz móvel, produzindo uma ilusão ótica. Pinturas bucólicas como árvores, plantas, animais ou então, fatos históricos, eram expostos, de modo bem realista, com fins instrutivos ou para mero entretenimento. Pintada sobre uma tela de fundo curvo, procurando simular um contorno real, era iluminada de certo modo, para passar a ideia de profundidade e movimento, dando a impressão de tridimensionalidade, além da redução compactada em escala para reforçar a ilusão de realismo. Os dioramas já despertavam interesse em Benjamin já em Berlim, em 1925, conforme atesta sua anotação da leitura do livro Daguerres Diorama in Berlin ("O
} 
tipos urbanos como a flânerie e o flâneur $^{10}$ e outros, foram temas caros a Baudelaire e que exerceram igual fascínio a Benjamin, que os via como índices concretos do moderno fenômeno urbano, assim como o fetiche da mercadoria, forma sígnica por excelência para expressar o desenvolvimento da economia capitalista da Paris do Século XIX (v. Premier exposé Paris, capitale du XIXeme siècle, le livre de passages). ${ }^{11}$

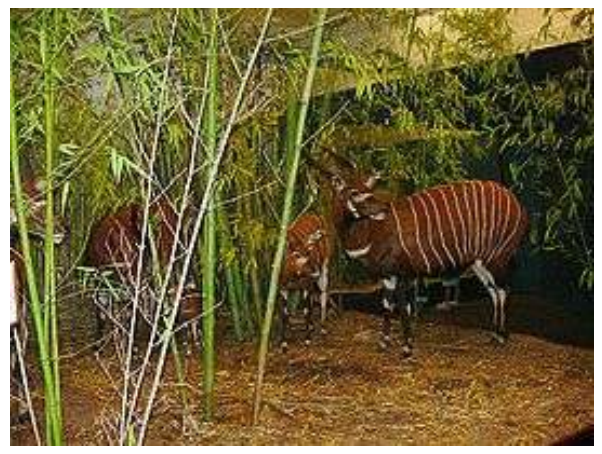

Diorama (paisagem)

No interior das multidões compactas desses novos lugares urbanos, constituídas de homens do mundo dos negócios, pessoas do grand monde parisiense, donas de casa, pintores, poetas e outros intelectuais e artistas de distintas naturezas, desempregados, transeuntes anônimos de diversos tipos e procedências, em frenética movimentação, encontra-se o flâneur, solitária personagem que, a um só tempo, integrada e afastada das multidões citadinas, a tudo observa, devaneando em seu pensar, deambulando pela cidade, com seu ritmo próprio. A flânerie torna-se uma prática difundida do seio da moderna sociedade parisiense.

Baudelaire, um homem pleno do século XIX, vive e capta intensamente esse momento em que o capitalismo industrial recém-instaurado molda a vida citadina dos grandes aglomerados, as pessoas, no interior das multidões, se chocam, as vitrines envidraças das galerias exibem fetiches mercadológicos, a última moda exposta

diorama de Daguerre em Berlim"), uma das obras citada na extensa lista dos livros de sua biblioteca (cf. Benjamin, 2000b, p.183).

10 O termo flanância, palavra não dicionarizada, é uma tradução bem livre de flânerie para significar o uso de sair perambulando pela cidade, sem destino, para "flertar" com o mundo e a vida.

11 Baudelaire, graças a uma larga poetica licentia, pode ser considerado uma espécie de alter ego poético de Benjamin, embora este divergiu do poeta em alguns temas, a exemplo do conceito de modernidade, bem como na apreciação positiva da fotografia, com possibilidades de portar valores estéticos "na era de sua reprodutibilidade técnica" ao contrário do francês. Além da obra dos próprios autores, é possível perceber tais divergências, dentre outros, nos seguintes textos: "Experiência da transitoriedade: Walter Benjamin e a modernidade de Baudelaire" (Luciano Gatti, 2009); e “Relativizando Baudelaire: uma releitura da crítica ao Salão de 1859” (Ronaldo Entler, 2007). 
sedutoramente, oferece-se ao consumo imediato, a fotografia, recém inventada, estabelece um novo olhar perceptivo.

\section{A poética da modernidade: $o$ ideal de belo}

A uma passante ${ }^{12}$

A rua em torno era um frenético alarido.

Toda de luto, alta e sutil, dor majestosa,

Uma mulher passou, com sua mão suntuosa,

Erguendo e sacudindo a barra do vestido;

Pernas de estátua. Era-lhe a imagem nobre e fina,

Qual bizarro basbaque, afoito, eu lhe bebia

No olhar, céu lívido onde aflora a ventania, A doçura que envolve e o prazer que assassina.

Que luz... e a noite após! - Efêmera beldade

Cujos olhos me fazem nascer outra vez, Não mais hei de te ver senão na eternidade?

Longe daqui! Tarde demais! nunca talvez!

Pois de ti já me fui, de mim tu já fugiste,

Tu que eu teria amado, ó tu que bem o viste!

No interior dessa multidão iremos encontrar o próprio Baudelaire, um flâneur especial, que, como o instantâneo de um clique fotográfico, capta os choques originários das multidões e os transmuda em inspiração poética da modernidade, como faz no seu belo soneto A une passante.

O poema adensa, de forma intensamente rica, o temário-síntese da poética baudelairiana, bem como princípios conceituais básicos que, segundo ele, devem presidir a inventiva do artista moderno: o tema recorrente da multidão no "frenético alarido" da rua; a passante, da qual, mesmo de forma fugaz, a sensibilidade do poeta, qual "bizarro basbaque", é capaz de sorver sua "dor majestosa"; a "imagem nobre e fina" fincada em "pernas de estátua", suporte clássico da eterna beleza clássica, que ganha presença coetânea na fluidez do clique veloz da efemeridade de uma piscadela; a expressão de sentimentos opostos, de "doçura e prazer" assassino, que dilaceram a alma do artista; o instante-já, um fugaz aqui/agora no arco de uma jornada completa: "que luz... e a noite após!"; a fugacidade da beleza imortalizada na "efêmera beldade" que não mais será vista "senão na eternidade"; o instantâneo fotográfico que, mesmo cada um tomando rumos opostos, "pois de ti já me fui, de mim tu já fugiste", tornou possível o poeta ver, amar e, ser percebido, pois “tu que eu teria amado, ó tu que bem o viste!"

\footnotetext{
${ }^{12}$ A une passante - Charles Baudelaire. Tradução de Ivan Junqueira
} 
Lugares mundanos, como lupanares e tavernas, exemplos de "mauvaises lieux", ${ }^{13}$ a moda e a multidão, com suas personagens como o trapeiro, o vendedor de vinho, o dandy, o conspirador, os velhos, temas e personagens recorrentes da vida moderna, bem como o épico contido no prosaísmo e costumes da vida da época, o spleen da modernidade (espécie de mal-estar de seu tempo), e, o que é mais importante, sua poética derivada desses novos eventos urbanos, postulam novos valores e sentidos estéticos diante do novo fazer artístico: o valor da imaginação criadora, a paixão subjetiva do artista, ${ }^{14}$ a crítica à arte mimética e o conceito de ideal relativo de belo, opondo-se ao belo ideal absoluto, constituem o corpus de uma nova estética tanto para o artista como para o fruidor de sua arte.

Como é sabido, partiu de Baudelaire o primeiro uso do termo modernidade, conforme lemos no famoso texto O pintor da vida moderna (cf. Poesia e prosa, 1995), cuja concepção foi gestada no seio da sua própria teoria do belo. Partindo da reflexão sobre a produção artística de sua época e de suas condições de possibilidade, o poeta conclui pela necessidade de formular uma teoria do belo que, a um só tempo, fosse racional (a porção absoluta e eterna do belo), e histórica (a porção relativa do belo), rompendo com a ideia clássica do belo da estética da tradição, cuja vigência, no mundo euro-ocidental, transpusera séculos. Sua noção de beleza deveria estar vinculada ao momento histórico do artista, cuja apreensão deve se dar na fugacidade do seu instante.

Segundo a noção baudelairiana, o belo é constituído por dois componentes, que se interpenetram, criando ambivalentemente sua configuração histórica. Um dos componentes é eterno, imutável; o outro é relativo, mutável, concernente a uma determinada época e a todas as especificidades que caracterizam tal época. A parte eterna só pode ser expressa mediada pelo elemento variável, que simultaneamente oculta e expressa o eterno. Só através dos traços que identificam uma época é que a idéia-forma do Belo, enquanto instância eterna, deve se efetivar, nunca por si mesma, mas envolta nas vestes que identificam uma determinada época. Daí Baudelaire afirmar que cada época possui sua própria beleza e que o belo sempre encontra satisfação na epocalidade inscrita na formalização estética do momento de sua representação.

\footnotetext{
${ }^{13}$ Cf. Berman, 1986, sobre a prosa de Baudelaire "A perda da auréola".

14 "O herói é o verdadeiro tema da modernité. Isto significa que para viver a modernidade é preciso uma formação heróica. [...].Balzac e Baudelaire se opõem ao romantismo. Sublimam as paixões e as forças de decisão; o romantismo sublima a renúncia e a dedicação" (Benjamim, 2000a, p.10).
} 
No texto $O$ pintor ..., Baudelaire critica grande parte dos artistas da época que tendia a negar a beleza do seu tempo, buscando-a no passado, fazendo com que o próprio teor da arte acabasse por se comprometer em obras obscuras e carentes de sentido e valor estéticos, visto que a "essência" estética presentificada no seu tempo, como conteúdo próprio da sua arte, não era retida em suas obras.

Afirma ainda que os artistas do período clássico, por isso mesmo chamados de clássicos, foram fiéis à sua época ao dela extraírem a beleza presente, captando a "essência" do seu entorno histórico. Mas tratava-se de representar, mediante formalizações estéticas da época, uma beleza idealizada, sem incorporar em suas obras, a beleza existente nos fenômenos cotidianos e, nesse aspecto, o artista moderno deve diferir-se, pois os clássicos são apenas fonte de estudo para conhecer a lógica e a técnica de suas criações.

\section{A subjetividade criadora}

O que diferencia os artistas de épocas distintas e o que determina sua singularidade devem prover da cultura e dos costumes de cada época, e de como essa experiência fica impressa na sua memória. A representação do belo é uma ação mediada pela subjetividade do artista, e o conteúdo de sua arte é o resultado da realidade vivenciada e filtrada por sua memória e expressa pelo seu sentimento. Sendo a subjetividade crucial no processo de criação, isso implica necessariamente rupturas com a concepção clássica do belo.

No Salão de $1846,{ }^{15}$ o crítico/poeta afirma ser o belo expresso pelo sentimento, devendo, por isso, prover-se das paixões e como estas são particulares, a beleza se manifesta de múltiplas formas. Portanto, ele deixa clara a impossibilidade de se

\footnotetext{
${ }^{15}$ Algumas reflexões dos Salões oficiais, objeto de textos críticos de Baudelaire, tiveram como referência a dissertação "A modernidade poética em Charles Baudelaire e Walter Benjamin" (2005), de Maria Gorete de Almeida, orientada pelo autor (programa de pós-graduação em Filosofia da UFC).

Sabe-se da importância que esses eventos exerceram no mundo da cultura e das artes francesas, ao definir estilos e tendências da estética da época. Dois deles marcaram inflexões e importantes rupturas. Em 1855, Gustave Courbet, tendo suas telas recusadas pelo Salão de Paris, construiu um rústico pavilhão próximo ao Salão, para expor quarenta e quatro delas, auto-nomeando tal gesto de Le Realisme, G.Courbet, que passou a designar todo o movimento, objeto de críticas de Baudelaire conforme analisamos acima. Em 1863, o Salon des Refusés (Salão dos Recusados) reuniu, numa mostra alternativa, várias obras de diversos artistas que tiveram suas telas rejeitadas pelo grande juri do Salão daquele ano, antecipando o movimento do Impressionismo que iria eclodir em 1874, com a participação de Auguste Renoir, Claude Monet, Edgar Degas, Alfrede Sisley,Berthe Morisot, dentre outros. Apesar da hostilidade ao Salão 1963, por parte do público em geral e de certos setores da imprensa conservadora, devido às ousadias dos jovens artistas afrontando os cânones da academia e do classicismo ainda vigente, Baudelaire toma partido das obras, por nelas perceberam marcas inovadoras da modernidade.
} 
compreender o belo mediante um viés acadêmico, enquanto único e absoluto, rompendo, dessa forma, com uma tradição que perdurou desde a antigüidade clássica até sua época, em meados do séc. XIX. Vivendo um tempo em que as academias possuíam um peso canônico no direcionamento da criação das artes, o poeta tece críticas acerbas aos "mestres" da arte que prescrevem as normas a serem seguidas pelo alunoartista, como se eles fossem os únicos depositários do saber verdadeiro sobre as artes.

Ainda profundamente vinculados à tradição clássica e insensíveis às profundas modificações pela qual transita a sociedade urbano-industrial, eles representam uma ameaça à própria arte. Esses "mestres-mandarim" (sic), a quem os artistas fazem juramentos, ameaçam liquidar a arte. Segundo Baudelaire, a única lei que o artista deve seguir é seu próprio sentimento do mundo. A liberdade torna-se a condição indispensável para a produção artística e a representação do belo. Os critérios a serem definidos para a criação só podem provir unicamente do próprio artista.

$\mathrm{Na}$ Exposição Universal de 1855, Baudelaire critica os mestres das academias, esses "modernos-professores em estética que são profundamente arraigados às normas" que proíbem "esse povo insolente de fruir, sonhar ou pensar através de procedimentos que não os seus" (Baudelaire, op.cit. p. 772s). Mais adiante, afirma que: "O artista depende apenas de si mesmo. Ele promete aos séculos vindouros somente suas próprias obras. Ele só responde por si próprio. Morre sem filho. Foi seu rei, seu sacerdote e seu Deus" (idem, p.776).

A questão da liberdade estética vincula-se organicamente à capacidade de imaginação do artista, faculdade crucial para a produção da obra de arte, por ser superior a todas as demais faculdades humanas, e que, por isso, devem se colocar a seu serviço. A imaginação é a rainha das faculdades, não se confundido com fantasia. É uma faculdade que analisa e sintetiza os fenômenos que serão expressos esteticamente. Por melhor que seja a técnica utilizada, se o artista for desprovido de imaginação certamente produzirá obras medíocres. A imaginação decompõe toda a criação e dá um novo ordenamento e configuração aos fragmentos do real, ressignificando-os.

Dotado de um olhar perceptivo aguçado, o artista parte de outra perspectiva, que retira do real fragmentado, o sentido que já lhe fora designado a fim de dar uma nova significação, ou seja, forma um novo sentido, ou, como quer Baudelaire, "produz a sensação do novo". Ele enfatiza o étimo comum ars ao termo arte e ao verbo articular, enquanto junção das partes: o artista é o ser capaz de juntar as partes na refiguração de um todo que ele dota de sentido estético. 
O entretecimento entre liberdade e imaginação deve-se à própria exigência da arte, uma vez que, sem imaginação não há criação e, por sua vez, a criação que segue os parâmetros da imaginação requer que o artista não dependa de normas pré-estabelecidas de uma estética canônica.

\section{Ruptura com a arte mimética}

A faculdade da imaginação como condição para se produzir arte verdadeira contrapõe-se à arte mimética. Para esta, enquanto cópia da natureza, a imaginação é totalmente descartável. No Salão de 1859, o autor afirma que a "cópia é inimiga da arte" e considera que a natureza não oferece nenhum critério de verdade. A natureza não pode ser copiada tal qual ela é, visto que não se conhece a natureza em-si. Ela se apresenta incompleta, restando ao artista dar cabo dessa incompletude, através de seu gesto estético. No Salão de 1846, afirma que o ideal de perfeição não existe, por isso não é possível uma imitação perfeita da natureza, pois esta é lacunar. Segundo o poeta,

“o ideal não é esta coisa vaga, esta coisa aborrecida e impalpável que flutua no teto das academias. Um ideal é um indivíduo reerguido pelo indivíduo, reconstruído e restituído pelo pincel ou pelo cinzel à radiosa verdade de sua harmonia primitiva" (p. 702).

Referindo-se ao pintor que utiliza a faculdade da imaginação, cita uma frase que Delacroix freqüentemente usava:

“ 'A natureza outra coisa não é senão um dicionário' [...]. Para bem compreender a amplitude do sentido implicado nessa frase, deve-se imaginar os usos ordinários e numerosos do dicionário. Neste, procurase o sentido das palavras, [...] enfim, extraem-se dele todos os elementos que compõem uma frase ou uma narrativa; mas ninguém jamais considerou o dicionário como uma composição, no sentido poético da palavra. Os pintores que obedecem à imaginação procuram em seu dicionário os elementos que se acomodam à sua concepção, e ainda ajustando-os com uma certa arte, dão-lhes uma fisionomia bem nova. Aqueles que não têm imaginação copiam o dicionário" (p. 887).

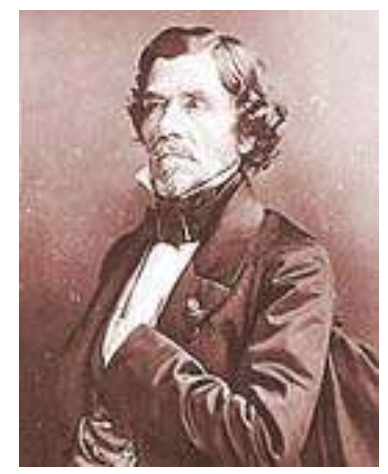

Eugène Delacroix (foto de Nadar - c. 1860) 
Baudelaire lê nessas palavras uma ampla fonte de pesquisa: a busca do sentido das palavras, i é, o sentido explícito não se encontra na própria natureza, mas, a partir dela, na subjetividade do artista. No caso, o pintor compõe a sua obra, faz sua própria leitura.

A veemente crítica de Baudelaire aos realistas origina-se dessas duas dimensões de sua poética: o uso da imaginação criadora e a ruptura com a arte mimética. Para ele, os realistas limitavam-se a copiar a realidade, não a partir de seus sentimentos e imaginação, senão a partir do que viam e julgavam ser o real em si. Os mesmos pressupostos estéticos que o levaram a assestar suas severas críticas aos realistas estão igualmente presentes no combate que trava contra a pintura paisagística.

Baudelaire, ao comentar os pintores paisagistas, reclama da falta de imaginação presente na maioria de suas obras. A imitação tão presente nesse estilo levou-o a afirmar, com tristeza e sarcasmo, que os paisagistas estão presos ao verdejante, ao copiar a natureza, denominando-os de "animais herbívoros".

Para o poeta, a paisagem não são campos, ervas e árvores, mas, principalmente, ruínas e, com tom melancólico, diz preferir toda a artificialidade dos dioramas, pois estes, pelo menos, sabem expressar a ilusão útil e contemplar cenários de teatro. O que é ostensivamente artificial, por não ter qualquer pretensão de se aproximar da natureza nem de parecer verdadeiro, mas apenas provocar um forte efeito, possui mais proximidade com a verdade, do que os paisagistas que continuam a imitar a natureza com o objetivo de representar o verdadeiro.

Tal atitude é contrária à arte, pois o elemento relativo do belo é expresso também pelo temperamento do artista. A imparcialidade adotada por determinados artistas, negando sua própria subjetividade, não permite que o belo seja expresso, por sua insistência numa arte mimética. O pintor moderno não deve expressar o que vê, mas o que sente e como sente. "Dia após dia a arte diminui o respeito por si mesma, prestando-se diante da realidade externa e o pintor torna-se cada vez mais inclinado a pintar, não o que ele sonha, mas o que ele vê" (p. 803).

Numa espécie de hermenêutica estética avant la lettre, para Baudelaire, o artista é, em si, um intérprete e o fruidor deve interpretar sua interpretação. Se o artista, ao elaborar a sua obra, faz uma tradução da realidade por ele vivenciada ou sonhada, essa tarefa distancia-se totalmente da cópia da natureza, e a intenção da arte é mesmo a de estabelecer o distanciamento da realidade ou da natureza, no sentido de fugir das garras da imitação e possibilitar que as imagens registradas na memória, expressas na obra de arte, recriem a natureza a partir da tradução feita pelo artista. 
De fato, toda a interpretação implica a explicitação das camadas de sentidos que podem estar contidos numa determinada obra-de-arte, do sentido explícito inscrito pelo artista ao sentido subjacente ao que está explícito, passando pelo sentido dado pelo espírito contemplante da obra.

As reflexões em $O$ Pintor..., anunciadas nos ensaios como o Salão de 1846, Salão Universal de 1855 e Salão de 1859, no que se refere, em especial, à sua relação com a arte mimética, deixam claro que a representação do belo, ou melhor dizendo, a expressão artística revela uma realidade muito mais verdadeira e nítida do que a própria realidade natural. A realidade exterior movimenta-se tão rapidamente, transforma-se a cada instante que não pode oferecer a menor segurança ou estabilidade. Por essa razão também a cópia da realidade não oferece nenhuma segurança.

A lembrança é algo registrado na memória e manifesto a partir de algum estímulo propiciado por fatores externos, sendo a memória o conjunto de impressões e registros adquiridos, via experiência, e é a partir dessas duas noções, memória e experiência, que o autor elabora sua teoria da estética, pilares sobre os quais a arte se ergue. As imagens devem ser extraídas da memória. A produção artística deverá ser o resultado do que foi observado e acumulado durante o dia na memória.

Existe, para ele, um modelo do artista moderno: o desenhista Constantin Guys (C.G.), ao descrever seu modo de observar seu entorno. Para ambos, Baudelaire e C.G., a observação é um ato indispensável que antecede o fazer artístico. Após colher todos os dados, a partir da observação dos acontecimentos diurnos, C.G. se lança em seus desenhos, executando-os com rapidez e atenção concentrada, temendo que algo possa cair no esquecimento antes de ser expresso no papel. Essa rapidez proposta é a tentativa de tudo extrair da memória, antes que algo se esvaeça (v. p. 854 e seguintes).

Não existe aí uma relação fidedigna com o que foi visto, ou com os fatos observados, mas como essas imagens se fixaram. C.G. é chamado de "homem do mundo" (p. 855), versado na arte da observação, da moda e dos costumes de sua época, sabendo mover-se em meio à multidão, sem nada deixar despercebido. As ideias não lhe chegam através da inspiração, mas do esforço intelectual árduo, do combate que empreende contra a fuga das impressões.

A agilidade necessária no processo de criação artística deve-se também ao tempo exterior ao sujeito, onde tudo transcorre velozmente. Daí a exigência de um fazer artístico num tempo mais rápido, mas com uma atenção muito aguçada, a fim de não 
perder um detalhe sequer retido na memória desses materiais "involuntariamente acumulados" adquiridos pela experiência do artista.

A figura de C.G. é recorrentemente mobilizada como modelo do artista moderno, ao vê-lo como um homem que conhece e compreende os mistérios do mundo, de suas causas e de seus costumes. Afirmando ser encantado pela multidão e, a um só tempo, mantendo-se oculto da mesma, esse grande observador se movimenta freneticamente nas grandes metrópoles. O prazer desse admirável observador consiste em residir no inconstante, no que não permanece.

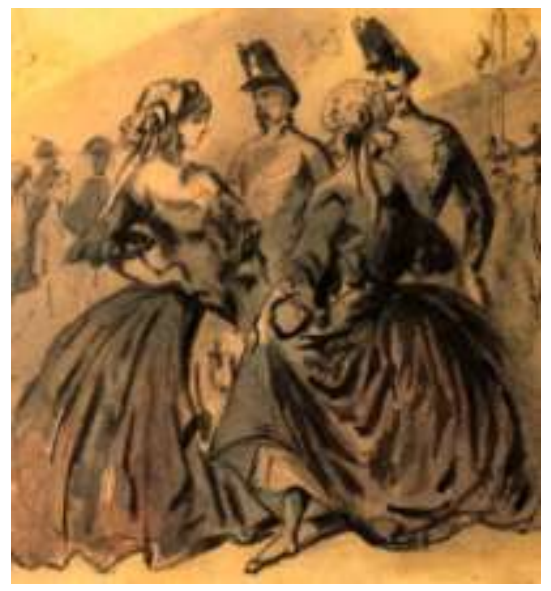

Duas moças e dois soldados (Constantin Guys)

Esse flâneur imerso em suas observações, mas a um só tempo, imerso anonimamente na própria multidão, o poeta compara a um "reservatório de energia" que nela penetra. Essa atitude corresponde à necessidade de trazer todo o movimento e energia da multidão para seu interior, como um alimento necessário para executar a sua produção artística.

Devido às constantes e rápidas mudanças ocorridas no cotidiano do artista, ele deverá estar atento em suas observações, tentando captar essa realidade fugaz, detendo, no curso do dia, o maior número de impressões possível. Para tanto, requer-se uma nova ótica, um olhar a partir de uma nova perspectiva que lhe possibilite, após ter apreendido o maior número de dados registrados em sua memória, expressá-los em sua obra. A isso Baudelaire, sempre pensando em C.G., atribui a tarefa do artista moderno.

Agora à hora que os outros estão dormindo, ele está curvado sobre sua mesa, lançando sobre uma folha de papel o mesmo olhar que há pouco dirigia às coisas, lutando com seu lápis, sua pena, seu pincel, lançando a água do copo até o teto, limpando a pena na camisa, apressado, violento, ativo, como se temesse que as imagens lhe escapassem, belicoso, mas sozinho, e debatendo-se consigo mesmo (p. 858s). 
A metáfora do poeta que empunha a pena como o esgrimista empunha sua arma encantava Benjamin. Conforme diz o filósofo, citando a passagem acima em que o poeta descreve o trabalho noturno criativo e rememorativo de C.G., "Baudelaire gostava de apresentar os [seus] traços marciais como traços artísticos. Quando descreve Constantin Guys de quem gostava, procura-o num momento em que os outros homens dormem" (2000a, p.5). A solitária "luta fantástica" travada por C.G./Baudelaire é retratada pelo poeta ao reverberá-la na primeira estrofe do poema Le soleil, conforme ressalta Benjamin. "O duelo de que participa todo o artista no qual 'solta um grito de terror antes de ser vencido' é conhecido como um idílio; a violência do duelo passa a segundo plano aparecendo apenas o seu encanto" (id., p. 6).

Sobre a cidade e o campo, os tetos e os trigais,

Exercerei a sós a minha estranha esgrima,

Buscando em cada canto os acasos da rima,

Tropeçando em palavras como nas calçadas,

Topando imagens desde há muito já sonhadas. ${ }^{16}$

A habilidade e a agilidade, como também a pressa que o artista deve executar a sua obra, como vimos, justificam-se na medida em que todas as imagens captadas durante o dia sejam expressas antes que se desvaneçam na sua memória. A forma de execução da atividade artística deverá corresponder ao mesmo processo empreendido durante as suas andanças à captura das imagens diurnas.

Em suma, nada escapou da pena de Baudelaire no que concerne ao mundo das artes e cultura de sua época. Assim se expressa o próprio artista/pensador a respeito da consciência do seu tempo: "Há momentos da nossa vida em que a duração do tempo se aprofunda e o sentimento da existência aumenta intensamente". Esse aprofundamento da duração do tempo sugere uma verticalização adensada, e nela a ideia de que esse tempo é estritamente reduzido, aquela fração de tempo que é capaz de condensar anos, ou seja, é um tempo tão curto e tão concentrado que possibilita forçosamente a autoconsciência do poeta.

O poeta/crítico se ocupou, praticamente, de todas as correntes estéticas e estilos que marcaram o século XIX: o Classicismo (francês), o Pré-Romantismo, o

\footnotetext{
${ }^{16}$ Tradução de Ivan Junqueira.

Sur la ville et les champs, sur les toits et les blés, Je vais m'exercer seul à ma fantasque escrime, Flairant dans tous les coins les hasards de la rime, Trébuchant sur les mots comme sus les pavés, Heurtant parfois des vers depuis longtemps revés.
} 
Romantismo, as pinturas paisagísticas, o Realismo e o Naturalismo. Antecipou-se ao Simbolismo do fim do século, em seus poemas de cunho místico-satânico. Só não se ocupou diretamente do Impressionismo, por ter morrido, como vimos, anos antes do aflorar do movimento, apesar de ter se colocado a favor de artistas do Salão dos Recusados, muitos deles futuros impressionistas e que foram hostilizados, pelo público, pela crítica e pelos professores identificados com os cânones do academicismo.

$\mathrm{O}$ artista/pensador Charles Baudelaire preparou uma nova seara, nela lançando sementes de estranhamento ao já estabelecido, cujos frutos seriam colhidos por gerações de artistas filiados às mais diferentes escolas e estilos, e que tiveram como afinidade estético-conceitual precisamente o empenho pela ruptura com aquele já estabelecido, gerações de artista que se reuniram, de modo bem amplo, sob a égide do que passou a ser conhecido como modernismo, efetivando a assertiva do artista/pensador de que a obra de arte deve trazer na sua constitutividade inescapável, as marcas do novo e daquela modernidade que lhe era tão cara, coetânea com o seu tempo. 


\section{REFERÊNCIAS}

ALMEIDA, Maria Gorete. A Modernidade Poética em Charles Baudelaire e Walter Benjamin, dissertação de Mestrado do programa de pós-graduação em Filosofia da UFC: 2005.

BAUDELAIRE, Charles. Poesia e prosa. Nova Aguilar Rio de Janeiro: 1995

BENJAMIM, Walter. Paris, Capitale du XIXe Siècle - Le Livre des Passages. Éditions du Cerf. Paris: 2009.

A modernidade e os modernos. Edições Tempo Brasileiro. Rio de Janeiro: 2000a.

http://pt.scribd.com/doc/2465690/BENJAMIN-Walter-A-modernidade-e-os-modernos Je déballe ma bibliothèque - une pratique de la collection. Rivages Poche. Petite Bibliothèque. Paris: 2000b. L'oeuvre d'art dans à l'époque de sa reproductibilité technique. Éditions Gallimard. Paris: 2008.

Pequena história da fotografia. Relógio D’Água Editores, Lisboa: 1992.

BERMAN, Marshall. Tudo que é sólido desmancha no ar. Companhia Das Letras, São Paulo: 1986.

DELORME, Jean-Claude e DUBOIS, Anne-Marie. Passages couverts parisiens. Paris, Parigrame: 2002.

ENTLER, Ronaldo. Relativizando Baudelaire: uma releitura da crítica ao Salão de 1859. XXX Congresso Brasileiro de Ciências da Comunicação da Sociedade Brasileira de Estudos Interdisciplinares da Comunicação - Santos: 2007.

Site: http://www.intercom.org.br/papers/nacionais/2007/resumos/R2208-2.pdf

GATTI, Luciano. "Experiência da transitoriedade: Walter Benjamin e a modernidade de Baudelaire" in revista Kriterion, vol.50 no.119, UFMG. Belo Horizonte: 2009.

MIRANDA, Dilmar. História da arte II - do romantismo à contemporaneidade. UECE/UAB. Fortaleza: 2010

NEEDELL, Jeffrey D. Belle Époque Tropical. Companhia Das Letras. São Paulo: 1993. 